\title{
PROJECT MATURITY OF ORGANIZATIONS IMPLEMENTING RESEARCH PROJECTS - PREPARING FOR QUESTIONNAIRE RESEARCH
}

\author{
Agata Klaus-Rosińska, ${ }^{1}$ Jan Betta ${ }^{2}$
}

\begin{abstract}
The purpose of this article is to provide a way of creating a maturity model for organizations implementing research projects. This will be done with an emphasis on constructing questionnaires to collect the necessary data. The result of the article is not the final version of the questionnaires but a guideline on how the construction can look like. The article presents also the reasons and explanations why maturity models in project the management area are important. The methods used in the article are literature review and lessons learned from previous experiences.
\end{abstract}

JEL Classification Numbers: D02, M21; DOI: http://dx.doi.org/10.12955/cbup.v5.1002

Keywords: maturity, project, questionnaire

\section{Introduction}

The issue of the research fits perfectly into the project management area, which importance from the last century growing all the time (Project Management Institute Inc., 2013). More and more organizations carry out their activities through projects, in addition there is a noticeable increase in the complexity of the projects. A new challenge for organizations is (among others) the multi-project environment (Spałek, 2013). For organizations implementing research projects a multi-project environment is visible. The development of "science" is carried out through projects (requirements of funding bodies) and the number of projects is increasing. The reason for this is the greater amount of possibilities of the funding for research projects, the need to raise the prestige of the organization and the need to develop the potential of the faculty's staff. According to Piecuch (2015), management of research projects is project management in a distributed and multi-project environment, which faces a number of problems. They are primarily related to:

- high rate of failures of projects, characterized by not achieving the intended outcomes within them,

- lack of good practices based on the team's experience which implemented the projects and after their completion were terminated,

- inefficient planning and use of human resources for the implementation of projects, mainly due to the creation of new teams often involving people without necessary experience in project management,

- lack of uniform standards of project management, which should be applied to all teams implementing projects,

- lack of control of the portfolio of projects implemented by the scientific institution.

Difficulties in project management in the university environment (so, in the typical research organization), have been identified in (Klaus-Rosińska and Zabłocka-Kluczka, 2014):

- rigid organizational structures that are unsuitable for the implementation of the project,

- lack of formal authority for projects and their managers,

- poor internal and external communication,

- inadequate or overly formalized project documentation,

- inadequate or poorly designed mechanisms of project quality management,

- lack of qualified project personnel.

Research project management is difficult. Their effective realization requires the organization having competences in the area of project management and the ability to manage multiple projects simultaneously (Piecuch, 2015). Research projects are characterized by a great diversity (in terms of the variously defined size of the project, the organizational structure, the stability of the project team, division of labour among the members of the project team, qualifications, degrees and titles held by members of the project team) (Birnbaum, 1977), which significantly makes their coordination hard.

\footnotetext{
${ }^{1}$ Department of Computer Science and Management, Wroclaw University of Science and Technology, e-mail: agata.klausrosinska@pwr.edu.pl

${ }^{2}$ Department of Computer Science and Management, Wroclaw University of Science and Technology, e-mail: jan.betta@pwr.edu.pl
} 
The project maturity model dedicated to organizations conducting research projects will assess the severity of applied solutions (implementation principles), methods and processes of research projects management. Performing an assessment of maturity in the organization of the research project management is the starting point for the continuous process of improvement in the area of research projects and performance of the whole organization. The findings of the evaluation would allow to get to know the strengths and weaknesses of the organization in relation to the management of research projects and thus to identify and determine the actions which should be taken in order to increase the effectiveness of the management of these projects. The results of the evaluation would also provide information about the causes of the problems identified for research projects and tell to stakeholders about the consequences of the usage of incorrect or non-uniform procedures. Also, the findings can indicate the organizational improvements which should be implement, resulting from the knowledge of project management (Piecuch, 2015; Rad and Levin, 2006).

\section{Project maturity models}

Maturity models in project management are related to the issue of maturity in economic sciences. The maturity here can be understood as the ability of the organization or/and its processes to improve and thus to bringing better results (Rosemann and de Bruin, 2005). The literature on the subject also referrers to the term of maturity level, which can be defined as the degree of achievement of the directives indicated by the adopted concept (Kucińska-Landwójtowicz and Kołosowski, 2012). The mentioned definitions indicate that maturity defines a path that an organization and/or processes goes through, along with getting experiences. The path is visible in maturity models.

In the project management area, there are many maturity models developed for specific branches, mainly for software and civil engineering industries. However, top researchers like Crawford (2006) or Kerzner (2001) regarding maturity in project management suggest designing a universal model assessing maturity for every type of organization. Since the last century a number of project management maturity models have been developed. It is possible to find more than 30 . The majority of these models indicate 5 maturity levels, where the first level is the 'initial' level (here there is no established project management practices), and level 5 is the 'optimising' level where the company is fully mature (Pretorius et al., 2012). In the literature often appear models like (Spałek, 2014):

- OPM3: Organizational Project Management Maturity Model,

- PMMM: Project Management Process Maturity Model,

- CMM: Capability Mature Model (and its improved version CMMI: Capability Maturity Model Integration),

- Prince 2 Maturity Model.

Nevertheless, we did not find the model of maturity in project management, which have been developed strictly for research projects (see more about maturity models related to research projects in Klaus-Rosińska, (2016)).

Considering the above mentioned statement, researchers from Wroclaw University of Technology intend to complement the knowledge of assessment with the maturity in research project management. The main objective of their research is to propose the concept of maturity assessment in the management of research projects, aimed at improving the performance of organizations implementing research projects. In order to achieve the main goal, it will be necessary to implement the specific objectives:

1. to examine the area of project management in organizations carrying out research projects in order to identify functional solutions and adopted strategies,

2. identification of the characteristics of research projects and their comparison with characteristics of other project types (IT projects and construction projects will be considered), which will help to determine the suitability of project management maturity models which are used in organizations conducting these types of projects on maturity assessment in research projects management,

3. to examine existing models of maturity in project management, showing their flaws, areas for improvement and to determine their fitness for assessing the maturity in research project management,

4. to propose a model of maturity in research project management and its initial verification, 
5. to develop a set of best practices (recommended paths) aimed at raising the level of maturity in research project management.

The research hypotheses are as follows:

- H1: In the organizations implementing research projects, there is a need to improve performance in the area of project management,

- H2: In organizations implementing research projects, models for assessing the project maturity are rarely used,

- H3: Organizations carrying out research projects, would await the development of a set of good practices (recommended paths) which help the achievement of higher levels of maturity in research project management,

- H4: Organizations which acquire experience in implementing research projects, improve the effectiveness of such projects.

\section{Preparation for questionnaire research}

In the study research methods like surveys, in-depth interviews with people from the area of project management (project managers, contractors, people of administrative support) and persons managing organizations implementing research projects will be applied (amongst others). For the purpose of conducting surveys and interviews, questionnaires to gather the material needed for fulfilling the specific objectives: (1), (2) and (3), will be developed.

The construction of the questionnaires will be based on:

1. previous but recent research, indicating critical success and failure factors for research projects (the project related to this topic is currently implemented at Wroclaw University of Science Technology, the title of the project is "Identification of success and failure factors of research projects", Grant no.: NCN 2014/13/B/HS4/01660, Funding agency: National Science Centre (NCN) in Poland, Funding period: from 2015-03-17 to 2017-03-16),

2. bibliographical overview of existing best practices in project management area (including research projects), and the analysis of them,

3. bibliographical overview of existing best practices of maturity models in project management area, and the analysis of them.

Showing how to develop questionnaires can be useful for:

- organizations carrying out research projects. They would need the development of appropriate questionnaires. Therefore, it can be a "good practice" for them too.

- researchers, people working inside research projects, who wants to do similar scientific works.

Taking into account four research points of view: the nature of the problem, the goal of the research, the underlying theory and the appropriate techniques (Miller and Salkind, 2002), the presented research is applied in one of them. The presented research is focused on a technique related to data gathering.

Sampling is one of natural methods of studying the stochastic phenomena. There is no unique quality standard necessary in each sampling. This quality depends on the stage of research work and on the destination of information being the sampling result (Rossi et al., 1983). Questionnaire are one of recognized and most important tools of sampling and data collection in applied research. The questionnaire is a self-completed document, which is filled in by respondents (Dornyei and Taguchi, 2009). The list of questions depends mostly on the author's creativity, who should take into account the time and cost restraints. The final quality depends on responder's perception and their answers. Both kinds of questions - open and closed - are admitted, but the authors should be conscious of advantages and disadvantages of both (Rossi et al., 1983).

Some recommendations of question formulation should be observed (Rossi et al., 1983):

- vocabulary should be simple,

- question shouldn't be too long,

- inappropriate questions specify alternatives rather than indicating one possibility,

- the questions should respect some psychological order,

- questions on one subject should be grouped, 
- length of the questionnaire depends on many factors, like psychological preparation of respondents,

- nature and quantity of resources needed,

- questionnaire format is important and should be chosen properly.

The questionnaire can contain three types of questions: factual, behavioural and attitudinal. General parameters of each questionnaire are: length layout and attention to sensitive subjects and anonymity. The main points of the questionnaire are: title, instructions, questions, complementary information and the closing part (Rossi et al., 1983).

\section{Conclusions}

The final construction of the questionnaires could be a useful tool for achievement of research objectives. It should accomplish all the principles of questionnaire development mentioned above, and conform to the classic "rules of art." The authors are conscious of the necessity to make this questionnaire as flexible as possible, because of the high level of complexity, innovation and incertitude of research projects.

\section{Acknowledgements}

Article is financed from the project "Identification of success and failure factors of research projects." Grant no. NCN 2014/13/B/HS4/01660. Funding agency: National Science Centre (NCN) in Poland.

\section{References}

Birnbaum, H. (1977). Assessment of alternative management forms in academic interdisciplinary research projects. Science. Vol. 24, No. 3, 272-284.

Crawford, J.K. (2006). The project management maturity model. Information Systems Management. 23(4), 50-58.

Dornyei, Z., Taguchi T. (2009). Questionnaires in Second Language Research, Routledge (first published August 1st 2002).

Kerzner, H. (2001). Strategic Planning for Project Management Using a Project Management Maturity Model. New York. Wiley.

Klaus-Rosińska, A., Zabłocka Kluczka, A. (2014). Project management in universities - the institutional aspect. International Business and Economics Research Journal. Vol. 13, No. 6, 1525-1538.

Klaus-Rosińska, A. (2016). Maturity model of project management in research projects: a synthesis of project management literature and directives for future research. 9th International Conference of Education, Research and Innovation ICERI2016 Conference Proceedings, Gómez Chova, L., López Martínez, A., Candel Torres, I. (Ed.), IATED Academy, 1947-1956

Kucińska-Landwójtowicz, A., Kołosowski M. (2012). Determinanty dojrzałości procesowej [in:] Innowacje w zarządzaniu i inżynierii produkcji. Oficyna Wydawnicza Polskiego Towarzystwa Zarządzania Produkcją. Opole, 655-663.

Miller, D.C., Salkind N. J. (2002). Handbook Research Design\&Social Measurement. 6th Edition. Sage Publications.

Piecuch, L. (2015). Organizacja Biura Wspierania Projektów na potrzeby rozwoju działalności badawczej uczelni wyższej i instytucji naukowej. Zarządzanie projektami w środowisku wieloprojektowym i rozproszonym. Opracowanie w ramach projektu: Międzynarodowa sieć wspierania badań i transferu wiedzy, jako płaszczyzna współpracy uczelni polskich i norweskich (nr projektu FSS/2013/IIC/W/0013). Kraków.

Pretorius, S., Steyn, H., Jordaan, J.C. (2012), South African Journal of Industrial Engineering. Vol. 23 (3), 1-12.

Project Management Institute Inc. (2013). A Guide to the Project Management Body of Knowledge (PMBoK Guide), 5th Edition. Polish version. Warsaw.

Rad, P.F., Levin, G. (2006). Project Management Office. Podejście kompleksowe. Wyd. PROED, Warszawa.

Rosemann, M., de Bruin, T. ( 2005). Towards a Business Process Management Maturity Model. ECIS 2005 Proceedings, 37.

Rossi, P. H., Wright J.D., Anderson A.B. (1983). Handbook of Survey Research, Academic Press, Orlando and London.

Spałek, S. (2013). Dojrzałość projektowa w zarządzaniu przedsiębiorstwem. Wydawnictwo Politechniki Śląskiej. Gliwice.

Spałek S. (2014). Zwiększanie stopnia dojrzałości w zarządzaniu projektami. Koncepcje, uwarunkowania i możliwe zastosowania praktyczne. Marketing i Rynek, 5/2014. 